УдК 006.03:657.6:005.936.3

DOI: $10.15673 /$ fie.v13i2.2045

Ткачук Г.О.

доктор економічних наук, доцент кафедра обліку та аудиту

E-mail: talla2007@ukr.net

ORCID ID: 0000-0001-6937-6223

\section{Скляр Л.Б.}

кандидат економічних наук, доцент кафедра обліку та аудиту

E-mail: sklyarlarisa17@gmail.com

ORCID ID: 0000-0002-8332-8823
Іванченкова Л.В.

доктор економічних наук, професор кафедра обліку та аудиту

E-mail: ivanchenkovalarisa@gmail.com

ORCID ID: 0000-0002-8461-7846

Ступницька Т.M.

кандидат економічних наук, доцент кафедра обліку та аудиту

Одеська національна академія харчових технологій вул. Канатна, 112, м. Одеса, Україна, 65039

E-mail: t.stupnitska@gmail.com

ORCID ID: 0000-0002-2517-2795

\title{
ПРОЦЕДУРИ АУДИТОРСЬКОГО ПІДТВЕРДЖЕННЯ ДОСТОВІРНОСТІ ФІНАНСОВОЇ ЗВІТНОСТІ: ВИРІШЕННЯ ПРОБЛЕМНИХ ПИТАНЬ
}

Актуальність напряму даного наукового дослідження обґрунтовується потребою у вдосконаленні теоретико-методологічного базису забезпечення достовірності фінансової звітності для прийняття рішень в системі управління. Узагальнено основні критерії аудиторської оцінки фрінансової звітності. Авторами виділено проблемні питання управління підприємством, які вирішуються шляхом проведення незалежного аудиту або застосуванням аудиторських процедур в системі внутрішнього контролю. Досліджена категорія «суттєвість» в аудиті фрінансової звітності, визначено її сутність та зміст за конкретними видами відповідно до вимог МСА. Надана характеристика чинників суттєвості на рівні конкретних класів операцій. Виділено аудиторські процедури для застосовування з метою забезпечення достовірності результатів аудиту фінансової звітності. Представлена класифікація напрямів вдосконалення аудиту фрінансової звітності відповідно до рівня їх реалізації. Запропоновано заходи 3 метою вдосконалення порядку організації та проведення аудиту фінансової звітності.

Ключові слова: аудит, аудиторський висновок, Міжнародні стандарти аудиту, фінансова звітність, суттєвість в аудиті, процедури аудиту, експертиза, управління підприємством.

This work is licensed under a Creative Commons Attribution 4.0 International License http://creativecommons.org/licenses/by/4.0/

Постановка проблеми та її зв'язок $з$ важливими науковими та практичними завданнями. В Україні компанії проводять фінансовий аудит, як і аудит фінансової звітності, або з ініціативи власника підприємства, чи в межах щорічної законодавчої перевірки звітності організацій, або для досягнення інших бізнес-цілей (зниження економічних ризиків, реорганізації компанії, покупки діючого бізнесу, виходу на нові ринки тощо). Аудиторська діяльність передбачає широкий спектр послуг у сфері фінансового аудиту:

1) огляд фінансової звітності, виконаної згідно 3 українськими національними стандартами i МСФ3;

2) аналіз дотримання облікової політики;

3) огляд внутрішнього контролю та оцінку ризиків; відність.

4) нормативно-правова та регуляторна відпо-

5) аудит фінансової звітності згідно з українськими національними стандартами та Міжнародними стандартами фінансової звітності.
Аудит фінансової звітності є важливою умовою забезпечення достовірності звітної інформації для прийняття управлінських рішень на сучасному підприємстві.

До того ж, впровадження незалежного аудиту в сферу підприємницької діяльності має істотні переваги загальнодержавного значення порівняно з іншими формами фінансово-господарського контролю, зокрема: значна економія державних коштів на утримання контрольно-ревізійного апарату; надходження додаткових коштів у бюджет за рахунок сплати аудиторськими фірмами (аудиторами-підприємцями) податків; незалежність, конкурентна боротьба, відповідний професіоналізм аудиторів, що сприяє підвищенню якості перевірок; можливість вибору аудитора замовником тощо [1].

Мета аудиту фінансових звітів відповідно до Міжнародного стандарту аудиту 200 «Мета та загальні принципи аудиту фінансових звітів» полягає в наданні аудиторові можливості висловити думку про те, чи складені фінансові звіти в усіх суттєвих аспектах відповідно до застосованої концептуальної осно- 
ви фінансової звітності [2]. У сфері аудиту існує таке поняття як рівень суттєвості - коли аудитор оцінює лише ті аспекти діяльності компанії, неправильний облік яких може призвести до істотним відхилень звітності.

Незважаючи на велику кількість нормативних документів - стандартів, якими регулюється аудиторська діяльність, безпосередньо фінансовий аудит та аудит фінансової звітності мають багато проблемних питань, вирішення яких $є$ підгрунтям забезпечення якості звітної інформації, яка використовується сучасними користувачами для прийняття управлінських рішень.

Аналіз останніх публікацій по проблемі. Тематика аудиту фінансової звітності не нова для сучасної економічної науки. Вагомий внесок у розвиток теорії і методології аудиту вже зробили провідні вітчизняні та зарубіжні автори: М.Т. Білуха, А.В. Бодюк, Я.А. Гончарук, Г.М. Давидов, Н.І. Дорош, О.А. Петрик, В.С. Рудницький, В.В. Сопко, Б.Ф. Усач, Р. Адамс, Е.А. Аренс, Е.Н. Гутцайт, Г.Р. Дженик, Р. Додж, Дж.К. Лоббек, Р.К. Маутц, В.І. Подольський, Дж. Робертсон, А.Д. Шеремет та інші.

Проте зміни у законодавчій базі здійснення аудиту, інтеграція вітчизняного бухгалтерського обліку до МСФО, зростання значимості раціонального застосування процедур аудиту відповідно до МСА, недостатній рівень методичного забезпечення аудиту фінансової звітності, що укладена за МСФЗ та інші проблемні аспекти обгрунтовують необхідність поглибленого вивчення суттєвості в аудиті та процедур забезпечення достовірності цього результатів.

Формулювання цілей дослідження. Мета даного наукового дослідження полягає у вдосконаленні теоретико-методологічного базису забезпечення достовірності аудиту фінансової звітності для прийняття рішень в системі управління. Для реалізації означеної мети нами поставлені та вирішені такі завдання:

1) виділення проблемних питань в системі управління підприємством, які вирішуються шляхом проведення незалежного аудиту;

2) виділення проблемних питань аудиту фінансової звітності;

3) узагальнення основних критеріїв аудиторської оцінки фінансової звітності;

4) дослідження категорії «суттєвість» в аудиті фінансової звітності;

5) виділення аудиторських процедур з метою забезпечення достовірності результатів аудиту фінансової звітності;

6) пропозиція теоретико-методологічних заходів вдосконалення аудиту фінансової звітності, які забезпечують вирішення проблемних питань системи управління.

Виклад основних результатів та їх обгрунтування. Нормативно-правовими (базовими) правилами, що регулюють аудит і якими обов'язково повинен користуватися аудитор при проведенні аудиту фінансової звітності підприємства $є$ : Міжнародні стандарти контролю якості, аудиту, огляду, іншого надання впевненості та надання супутніх послуг (Між- народні стандарти аудиту) [2]; Закон України «Про аудит фінансової звітності та аудиторську діяльність в Україні» [3]; Закон України «Про бухгалтерський облік та фінансову звітність» [4]; Національні положення (стандарти) бухгалтерського обліку [5]; документи Аудиторської палати України, що регулюють аудиторську діяльність тощо.

Значення міжнародних правил (стандартів) полягає в тому, що вони [6]: перевірки;

1) забезпечують високу якість аудиторської

2) сприяють запровадженню в аудиторську практику наукових досягнень;

3) допомагають користувачам зрозуміти процес аудиторської перевірки;

4) допомагають аудиторам вести переговори 3 клієнтами;

5) забезпечують зв'язок між окремими елементами аудиторського процесу;

6) раціоналізують та полегшують працю аудиторів тощо.

До того ж, дотримання вимог аудиторських стандартів забезпечує виконання таких професійних якостей як незалежність та компетентність [7].

Таким чином, важливим проблемним аспектом аудиту фінансової звітності $є$ повне якісне нормативне забезпечення відповідно до міжнародних вимог кожного етапу організації, планування, проведення аудиту, узагальнення його результатів, етики ділового спілкування під час аудиту, забезпечення незалежності аудиторської думки, контролю якості аудиторської діяльності. Важливість дотримання вимог МСА задля досягнення необхідного рівня якості аудиторського висновку, також підтверджує необхідність вирішення проблеми повноти застосування окремих МСА, а саме, Міжнародні стандарти аудиту необхідно застосовувати у повній мірі, а не тільки в загальних питаннях організації та оформлення результатів перевірки.

Керуючись концептуальними положеннями фінансової звітності, яка встановлена Законом України «Про бухгалтерський облік та фінансову звітність в Україні» [4] й НП(С)БО 1 «Загальні вимоги до фінансової звітності» [6] та сучасними науковими підходами [5], основними критеріями аудиторської оцінки фінансової звітності доречно вважати: достовірність, зрозумілість, повноту, доречність, суттєвість, нейтральність, безперервність, відповідність. В табл. 1 наведено зміст виділених критеріїв та пояснення до нього.

Проблемними питаннями в системі управління підприємством, які вирішуються шляхом проведення незалежного аудиту фінансової звітності або застосуванням аудиторських процедур в системі внутрішнього контролю підприємства є:

1) недостовірність вхідної обліково-звітної інформації для прийняття управлінських рішень, наявність суттєвих помилок та фальсифікацій;

2) недобросовісність або низький рівень фахової компетентності укладачів звітної інформації;

3) відсутність на підприємстві дієвих технологій контролю якості обліку та звітності. 
Критерії аудиторської оцінки фінансової звітності *

\begin{tabular}{|c|c|c|}
\hline $\begin{array}{l}\text { Критерії } \\
\text { оцінки }\end{array}$ & Зміст критерія & Пояснення до змісту критерія \\
\hline Достовірність & $\begin{array}{l}\text { Інформація, наведена у фінансовій звіт- } \\
\text { ності, є достовірною, якщо вона не } \\
\text { мстить помилок та перекручень, які здат- } \\
\text { ні вплинути на рішення користувачів зві- } \\
\text { тності }\end{array}$ & $\begin{array}{l}\text { Достовірність досягається дотриманням ви- } \\
\text { мог НП(С)БО або МСФЗ. Достовірне подан- } \\
\text { ня вимагає вибирати та застосовувати ін- } \\
\text { струменти облікової політики відповідно до } \\
\text { стандартів обліку }\end{array}$ \\
\hline Зрозумілість & $\begin{array}{l}\text { Інформацію у фінансовій звітності викла- } \\
\text { дено чітко та зрозуміло }\end{array}$ & $\begin{array}{l}\text { Звітна інформація подається відповідно до } \\
\text { НП(С)БО (МСФЗ), робочого Плану рахунків, } \\
\text { облікової політики підприємства та націона- } \\
\text { льної практики укладання приміток }\end{array}$ \\
\hline Повнота & $\begin{array}{l}\text { У фінансових звітах не допускається } \\
\text { пропуск операцій, подій, залишків на ра- } \\
\text { хунках, які можуть впливати на рішення, } \\
\text { що приймаються на їх основі }\end{array}$ & $\begin{array}{l}\text { У фінансовій звітності за МСФЗ відобража- } \\
\text { ються всі суттєві операції, події, рахунки. У } \\
\text { фінансовій звітності, яка укладена за } \\
\text { НП(С)БО, виняток для несуттєвих подій не } \\
\text { передбачено }\end{array}$ \\
\hline Доречність & $\begin{array}{l}\text { Інформація, наведена у фінансовій звіт- } \\
\text { ності, } є \text { доречною до характеру суб’єкта } \\
\text { господарювання та мети фінансових зві- } \\
\text { тів }\end{array}$ & $\begin{array}{l}\text { Фінансова звітність повинна містити лише } \\
\text { доречну інформацію, яка впливає на прийн- } \\
\text { яття рішень користувачами, дає змогу } \\
\text { вчасно оцінити минулі, теперішні та май- } \\
\text { бутні події, підтвердити та скоригувати їхні } \\
\text { оцінки }\end{array}$ \\
\hline Суттєвість & $\begin{array}{l}\text { Інформація є суттєвою, якщо ії відсут- } \\
\text { ність або неправильне подання може } \\
\text { вплинути на рішення, які приймають ко- } \\
\text { ристувачі на основі фінансової інформа- } \\
\text { ції про конкретний суб'єкт господарю- } \\
\text { вання }\end{array}$ & $\begin{array}{l}\text { Фінансова звітність } є \text { результатом обробки } \\
\text { великої кількості операцій або інших подій, } \\
\text { які об’єднують у класи згідно з їх характе- } \\
\text { ром чи функцією. Інформація подається у } \\
\text { стислій і класифікованій формі у відповідних } \\
\text { рядках фінансових звітів }\end{array}$ \\
\hline Нейтральність & $\begin{array}{l}\text { Відсутність упередженості у відборі або } \\
\text { поданні фінансової інформації }\end{array}$ & $\begin{array}{l}\text { Нейтральність передбачає, що різні компо- } \\
\text { ненти мають різну вагу, та відсутнє необгру- } \\
\text { нтоване збільшення або зменшення значи- } \\
\text { мість окремих компонентів з метою маніпу- } \\
\text { ляції сприйняттям користувачів }\end{array}$ \\
\hline Безперервність & $\begin{array}{l}\text { Укладаючи фінансову звітність, оціню- } \\
\text { ється здатність суб'єкта господарювання } \\
\text { продовжувати свою діяльність на безпе- } \\
\text { рервній основі }\end{array}$ & $\begin{array}{l}\text { Фінансову звітність складають на основі } \\
\text { безперервності, якщо тільки управлінський } \\
\text { персонал не має намірів ліквідувати суб’єкт } \\
\text { господарювання чи припинити діяльність } \\
\text { або не має реальної альтернативи таким за- } \\
\text { ходам }\end{array}$ \\
\hline Відповідність & $\begin{array}{l}\text { Відповідність концептуальним засадам } \\
\text { НП(С)БО, або МСФЗ }\end{array}$ & $\begin{array}{l}\text { Принципи відповідності доречно відобража- } \\
\text { ти в обліковій політиці підприємства }\end{array}$ \\
\hline
\end{tabular}

*Узагальнено авторами за аналізом джерел $[4 ; 5 ; 8]$

Для вирішення зазначених проблемних питань в міжнародній та національній практиці широко використовують технології зовнішнього та внутрішнього аудиту. Думка аудитора про достовірність або недостовірність фінансової звітності повинна базуватись на зібраних в ході аудиту необхідних і достатніх доказів - документальних підтверджень.

Зазначимо, що фінансова звітність є важливим джерелом інформації для прийняття управлінських рішень щодо: забезпечення ефективності поточної господарської діяльності; поточного та стратегічного планування; забезпечення ефективного внутрішньогосподарського контролю тощо. Простежується зрозуміла взаємозалежність: результативність рішень в системі управління підприємством напряму залежить від достовірності та якості джерел інформації (фінансової звітності), на підставі яких ці рішення приймаються. В свою чергу, достовірність фінансової звітності забезпечується висновком незалежного аудиту. При цьому адекватність аудиторського висновку напряму залежить не тільки від рівня професійної компетентності аудитора, але й від суттєвості та якості аудиторських процедур.

Сучасні науковці приділяють багато уваги термінам «достовірність фінансової звітності», «достовірність аудиту», «достовірність облікової інформації». НП(С)БО 1 «Загальні вимоги до фінансової звітності» визначає, що інформація, наведена у фінансовій звітності, є достовірною, якщо вона не мстить помилок та перекручень, які здатні вплинути на рішення користувачів звітності [5].

Розкриваючи зміст категорії «достовірність» 
досить часто використовують такі поняття як «фальсифікована звітність», «прикрашена звітність», «спотворена звітність», «викривлена звітність», «звітність, що містить перекручення, завуальовані дані, приписки» [9], що обгрунтовує необхідність застосування в аудиті спеціальних процедур для виявлення таких негативних явищ та оцінки ризикованості висловлення недостовірної аудиторської думки.

Достовірність звітної інформації, яка використовується для прийняття управлінських рішень, напряму пов'язана із якістю незалежного аудиту. В свою чергу, основні передумови забезпечення дієвості аудиту фінансової звітності передбачають застосування:

- якісних стандартів аудиторської діяльності, які відповідають міжнародним стандартам аудиту (MCA);

- чітких правил незалежності аудиторських організацій та аудиторів;

- єдиних кваліфікаційних вимог до аудиторів незалежно від того, в якій галузі та сфері економіки вони ведуть діяльність;

- високого кваліфікаційного рівня (у тому числі в області МСФЗ) аудиторів, який забезпечувався б системою атестації та підвищення кваліфікації;

- контролю якості роботи аудиторських організацій та аудиторів передусім із боку професійних громадських об'єднань;

- ефективної системи державногромадського нагляду за аудиторськими організаціями й аудиторами [10].

Міжнародний стандарт аудиту (MCA) 320 «Суттєвість при плануванні та проведенні аудиту» визначає основні положення стосовно суттєвості в аудиті, а саме:

1) викривлення вважаються суттєвими, якщо «обгрунтовано очікується, що вони, окремо або в сукупності, можуть вплинути на економічні рішення користувачів, які приймаються на основі фінансової звітності»;

2) Судження щодо суттєвості здійснюються «з урахуванням супутніх обставин і залежать від розміру або характеру викривлення, або їх поєднання»;
3) Судження щодо питань, які є суттєвими для користувачів фінансової звітності, «здійснюються на основі розуміння загальних потреб у фінансовій інформації користувачів як групи». Можливий вплив викривлень на окремих користувачів, потреби яких можуть значно відрізнятися, не розглядається.

В наукових колах дефініцію «суттєвість» розглядають як:

1) скоріше певний поріг або «критерій відсікання, а не основну якісну характеристику, яка повинна бути притаманна інформації, щоб вона стала корисною» [11].

2) властивість інформації, яка робить іiі здатною впливати на економічні рішення користувача [12];

3) властивість інформації, що «формує межу, яка, своєю чергою, змінює характеристику та зміст виконуваних аудиторських послуг» [13].

При плануванні аудиту аудитор застосовує судження щодо викривлень, що будуть вважатися суттєвими. Такі судження $є$ основою для:

1) визначення характеру, часу та обсягу процедур оцінювання ризиків;

2) ідентифікації та оцінювання ризиків суттєвого викривлення;

3) визначення характеру, часу та обсягу подальших аудиторських процедур.

Визначають три види суттєвості аудиту (табл. 2):

1) Суттєвість на рівні фінансової звітності в цілому

2) Суттєвість на рівні конкретних класів операцій; процедур

3) Суттєвість для виконання аудиторських

Відповідно до МСА 320 «ідентифікація та визначення ризиків суттєвого викривлення включає застосування професійного судження для ідентифікації тих класів операцій, залишків рахунків та розкриттів, включаючи якісні розкриття, викривлення яких може бути суттєвим».

Види суттєвості аудиту відповідно до МСА 320 «Суттсвість при плануванні та проведенні аудиту»*

\begin{tabular}{|c|c|c|}
\hline $\begin{array}{c}\text { Види суттєвості } \\
\text { за МСА }\end{array}$ & Визначення за МСА 320 & Мета застосування \\
\hline $\begin{array}{l}\text { 1. Суттєвість на рів- } \\
\text { ні фінансової звіт- } \\
\text { ності в цілому }\end{array}$ & $\begin{array}{l}\text { Означає суму або суми, визначені аудитором на } \\
\text { рівні, нижчому від суттєвості для фінансової звіт- } \\
\text { ності в цілому, для того, щоб знизити до прийнятно } \\
\text { низького рівня ймовірність того, що сукупність } \\
\text { невиправлених та невиявлених викривлень пере- } \\
\text { вищить розмір суттєвості для фінансової звітності } \\
\text { в цілому }\end{array}$ & $\begin{array}{c}\text { Для визначення загальної } \\
\text { стратегії аудиту }\end{array}$ \\
\hline $\begin{array}{c}\text { 2. Суттєвість на рів- } \\
\text { ні конкретних кла- } \\
\text { сів операцій }\end{array}$ & \multicolumn{2}{|c|}{$\begin{array}{l}\text { Якщо за конкретних обставин суб’єкта господарювання існує один або кілька окре- } \\
\text { мих класів операцій, залишків рахунків або розкриття інформації, для яких обгрун- } \\
\text { товано очікується, що викривлення, нижчі від рівня суттєвості, прийнятого на рівні } \\
\text { фінансової звітності в цілому, можуть вплинути на економічні рішення користува- } \\
\text { чів, прийнятих на основі фінансової звітності, аудитор має також визначити рівень } \\
\text { або рівні суттєвості, що застосовуватимуться до цих конкретних класів операцій, } \\
\text { залишків на рахунках та розкриття інформації }\end{array}$} \\
\hline
\end{tabular}


Продовження табл. 2

\begin{tabular}{|c|c|c|}
\hline $\begin{array}{c}\text { Види суттєвості } \\
\text { за МСА } \\
\end{array}$ & Визначення за МСА 320 & Мета застосування \\
\hline $\begin{array}{l}\text { 3. Суттєвість для } \\
\text { виконання аудитор- } \\
\text { ських процедур } \\
\text { (performance } \\
\text { materiality) }\end{array}$ & $\begin{array}{l}\text { Стосується суми або сум, визначених аудитором у } \\
\text { розмірі, нижчому від рівня (рівнів) суттєвості для } \\
\text { окремих класів операцій, залишків рахунків та роз- } \\
\text { криття інформації }\end{array}$ & $\begin{array}{l}\text { Для оцінки ризиків суттєвого } \\
\text { викривлення та визначення } \\
\text { змісту, часу виконання й об- } \\
\text { сягу подальших аудиторських } \\
\text { процедур }\end{array}$ \\
\hline
\end{tabular}

*Узагальнено авторами за аналізом джерел [2]

Аудитором ідентифікуються такі чинники, як:

1) обставини суб'єкта господарювання протягом періоду;

2) застосована концептуальна основа фінансового звітування, включаючи зміни в ній;

3) якісні розкриття, що є важливими для користувачів фінансової звітності внаслідок характеру суб'єкта господарювання.
На рис. 1 наведено чинники, що можуть вказувати на наявність одного або більшої кількості певних класів операцій, залишків рахунків або розкриття інформації, для яких обгрунтовано очікується викривлення у меншому розмірі, ніж суттєвість на рівні фінансової звітності в цілому, а також приклади до них.

Чинники, що можуть вказувати на наявність одного або більшої кількості певних класів операцій, залишків рахунків або розкриття інформації, для яких обгрунтовано очікується викривлення у меншому розмірі, ніж суттєвість на рівні фінансової звітності в цілому

\begin{tabular}{|c|c|c|}
\hline $\begin{array}{c}\text { Чи впливають законодавчі та нормативні } \\
\text { акти або застосовна концептуальна основа } \\
\text { фінансового звітування на очікування корис- } \\
\text { тувачів стосовно вимірювання або розкриття } \\
\text { окремих статей }\end{array}$ & $\begin{array}{c}\text { Основні розкриття ін- } \\
\text { формації для галузі, в } \\
\text { якій діє суб'єкт госпо- } \\
\text { дарювання }\end{array}$ & $\begin{array}{c}\text { Чи зосереджена увага на } \\
\text { конкретному аспекті біз- } \\
\text { несу суб'єкта господарю- } \\
\text { вання, що окремо розкри- } \\
\text { вається у фінансовій звіт- } \\
\text { ності }\end{array}$ \\
\hline $\begin{array}{c}\text { Наприклад: } \\
\text { операції з пов’язаними сторонами та оплата } \\
\text { праці управлінського персоналу і тих, кого } \\
\text { наділено найвищими повноваженнями, та } \\
\text { аналіз чутливості для облікових оцінок за } \\
\text { справедливою вартістю з високою непевніс- } \\
\text { тю) }\end{array}$ & $\begin{array}{c}\text { Наприклад: } \\
\text { витрати на науково- } \\
\text { дослідні та дослідно- } \\
\text { конструкторські роботи }\end{array}$ & $\begin{array}{c}\text { Наприклад: } \\
\text { розкриття щодо сегментів } \\
\text { або значних частин бізнесу }\end{array}$ \\
\hline
\end{tabular}

Рис. 1. Чинники суттєвості на рівні конкретних класів операцій * *складено авторами за аналізом джерел [2]

Визначення аудитором суттєвості є предметом професійного судження та залежить від «розуміння аудитором потреб користувачів фінансової звітності у фінансовій інформації. За таких умов аудитору доцільно припустити, що користувачі» [2]:

1) мають достатнє знання бізнесу, економічної діяльності та бухгалтерського обліку, а також готові вивчати інформацію у фінансовій звітності 3 належною ретельністю;

2) розуміють, що фінансову звітність підготовлено, надано й перевірено $з$ урахуванням рівнів суттєвості;

3) визнають невизначеність, притаманну вимірюванню сум, що грунтуються на оцінках, судженнях і розгляді майбутніх подій;

4) приймають обгрунтовані економічні рішення на основі інформації, що міститься у фінансо- вій звітності.

Важливим та проблемним питанням $є$ визначення процедур ідентифікації викривлень фінансової звітності.

Згідно із тлумаченням «словника української мови», процедура в контексті теми нашого дослідження - це «офіційно встановлений чи узвичаєний порядок здійснення, виконання або оформлення» аудиту фінансової звітності [14].

Міжнародними стандартами контролю якості, аудиту, огляду, іншого надання впевненості та надання супутніх послуг окремим стандартом виділено лише аналітичні процедури (МСА 520), хоча окремі процедури різної направленості та рівня, пов'язані із плануванням, проведенням, отриманням доказів, оформленням результатів тощо $є$ майже у кожному MCA [2]. 
Аналіз нормативного забезпечення організації та проведення аудиту на рівні Міжнародних стандартів аудиту доводить доречність та необхідність використання в аудиті фінансової звітності аудиторських процедур для забезпечення достовірності аудиторського висновку. До таких процедур віднесено:

- процедури використання матеріалів попередніх аудитів (MCA 330). Дозволяють проконтролювати помилки та неузгодженості даних попереднього періоду та уникнути їх в майбутньому шляхом призначення додаткових аудиторських процедур;

- оцінювання достатності та прийнятності аудиторських доказів (МСА 330). Аудиторська думка стосовно достовірності фінансової звітності підтверджується аудиторськими доказами, які мають бути достатніми та адекватними. Їх наявність на відповідному рівні забезпечує законність такої аудиторської думки;

-процедури зовнішнього підтвердження (MCA 505). Часто виконуються для отримання підтвердження або звернення щодо інформації про залишки рахунків та їх елементи. Вони також можуть використовуватися для підтвердження умов угод, конт- рактів або операцій між суб'єктом господарювання та іншими сторонами або для підтвердження відсутності певних умов, таких як «додаткова угода». При цьому нагадаємо, що аудиторські докази є більш надійними, що їх отримано 3 незалежних джерел за межами суб'єкта господарювання;

-аналітичні процедури (МСА 520). Відповідно до МСА 520 «Аналітичні процедури» термін «аналітичні процедури» («analytical procedures») означає «оцінки фінансової інформації, зроблені на основі аналізу очікуваних взаємозв'язків між фінансовими та нефінансовими даними, що охоплюють необхідне вивчення ідентифікованих відхилень або взаємозв'язків, які не узгоджуються 3 іншою доречною інформацією чи значно відрізняються від очікуваних величин.

- процедура використання роботи експерта (MCA 620). Залучення експерта за окремими питаннями щодо підтвердження статей фінансової звітності значно підвищує якість аудиту та достовірність його результатів.

В табл. 3 систематизовано базові дії аудитора щодо застосування зазначених процедур.

Таблиця 3

Базові дії аудитора \#щодо застосування процедур аудиту фінансової звітності*

\begin{tabular}{|c|c|}
\hline Процедури аудиту & Дії аудитора \\
\hline $\begin{array}{l}\text { 1. Використання ма- } \\
\text { теріалів поперед- } \\
\text { ніх аудитів } \\
\text { (МСА } 330 \text { «Діє аудитора у } \\
\text { відповідь на оцінені ризи- } \\
\text { ки») }\end{array}$ & $\begin{array}{l}\text { 1) якщо були зміни, які впливають на подальшу доречність аудиторських дока- } \\
\text { зів попереднього аудиту, аудитор повинен виконати тести заходів контролю під } \\
\text { час поточного аудиту; } \\
\text { 2) якщо таких змін не було, аудитор повинен виконати тести заходів контролю } \\
\text { щонайменше один раз під час кожного третього аудиту та тести деяких заходів } \\
\text { контролю під час кожного аудиту з тим, щоб уникнути можливості тестування } \\
\text { всіх заходів контролю, яким аудитор планує довіряти, під час одного періоду } \\
\text { аудиту, не виконуючи тести заходів контролю під час двох наступних періодів } \\
\text { аудиту; } \\
\text { 3) аудитор повинен розглянути, чи слід виконати процедури зовнішнього підт- } \\
\text { вердження як аудиторські процедури по суті. }\end{array}$ \\
\hline $\begin{array}{l}\text { 2. Оцінювання достатнос- } \\
\text { ті та прийнятності ауди- } \\
\text { торських доказів (МСА } \\
330 \text { «Діє аудитора у від- } \\
\text { повідь на оцінені ризики») }\end{array}$ & $\begin{array}{l}\text { 1) виходячи з виконаних аудиторських процедур та отриманих аудиторських } \\
\text { доказів аудитор повинен оцінити до завершення аудиту, чи залишається прийн- } \\
\text { ятною оцінка ризиків суттєвого викривлення на рівні тверджень; } \\
\text { 2) аудитор повинен прийняти рішення, чи отримано прийнятні аудиторські до- } \\
\text { кази у достатньому обсязі; } \\
\text { 3) якщо аудитор не отримав прийнятних аудиторських доказів у достатньому } \\
\text { обсязі стосовно будь-якого суттєвого твердження у фінансовій звітності, він } \\
\text { повинен намагатися отримати подальші аудиторські докази, висловити думку із } \\
\text { застереженнями або відмовитися від висловлення думки щодо фінансової звіт- } \\
\text { ності. }\end{array}$ \\
\hline $\begin{array}{l}\text { 3. Процедури зовнішнього } \\
\text { підтвердження } \\
\text { (МСА } 505 \text { «Зовнішні під- } \\
\text { твердження») }\end{array}$ & $\begin{array}{l}\text { 1) визначити інформацію для підтвердження або звернення; } \\
\text { 2) здійснити вибір належної сторони, що надає підтвердження; } \\
\text { 3) сформулювати звернення щодо підтвердження, включаючи визначення на- } \\
\text { лежного одержувача звернень і наявність інформації для надсилання відповідей } \\
\text { безпосередньо аудитору; } \\
\text { 4) надсилання звернень та їх обробка. }\end{array}$ \\
\hline $\begin{array}{l}\text { 4. Аналітичні процедури } \\
\text { (МСА } 520 \text { «Аналітичні } \\
\text { процедури») }\end{array}$ & $\begin{array}{l}\text { 1) визначити придатність конкретних аналітичних процедур по суті для суттє- } \\
\text { вих тверджень фінансової звітності із урахуванням оцінених ризиків суттєвого } \\
\text { викривлення, а також тестів деталей, якщо такі є, для цих тверджень ; } \\
\text { 2) оцінити надійність даних, на які спирається аудитор під час попереднього } \\
\text { розрахунку відображених сум або коефіцієнтів, беручи до уваги джерело, порі- } \\
\text { внянність, характер і відповідність доступної інформації, та заходи внутрішньо- } \\
\text { го контролю за підготовкою фінансової звітності; }\end{array}$ \\
\hline
\end{tabular}


Продовження табл. 3

\begin{tabular}{|c|c|}
\hline $\begin{array}{c}\text { Процедури } \\
\text { аудиту }\end{array}$ & Дії аудитора \\
\hline & $\begin{array}{l}\text { 3) здійснити попередні розрахунки відображених сум і коефіцієнтів та оцінити те, чи } \\
\epsilon \text { вони досить точними для ідентифікації викривлення, яке окремо або разом з інши- } \\
\text { ми викривленнями може призвести до суттєвого викривлення фінансової звітності; } \\
\text { 4) визначити обсяг будь-якої розбіжності відображених сум } 3 \text { очікуваними значен- } \\
\text { нями, яка є прийнятною і не потребує подальшого розгляду. }\end{array}$ \\
\hline $\begin{array}{l}\text { 5. Процедура вико- } \\
\text { ристання роботи } \\
\text { експерта (МСА } 620 \\
\text { «Використання ро- } \\
\text { боти експерта ауди- } \\
\text { тора») }\end{array}$ & $\begin{array}{l}\text { 1) визначення характеру, часу та обсягу аудиторських процедур; } \\
\text { 2) визначення необхідності використання роботи експерта аудитора; } \\
\text { 3) оцінює компетентність, уміння та об’єктивність експерта аудитора } \\
\text { 4) отримання розуміння галузі спеціальних знань експерта аудитора } \\
\text { 5) укладає угоду з експертом } \\
\text { 6) здійснює Оцінювання достатності роботи експерта аудитора. }\end{array}$ \\
\hline
\end{tabular}

*Авторська розробка за аналізом джерел [2]

Таким чином, злободенні проблеми аудиту фінансової звітності, які суттєво впливають на якість управлінських рішень, які приймаються за аналізом цієї звітності, пов'язані із:

1) повнотою та якістю нормативного покриття кожного етапу організації, планування, проведення аудиту, узагальнення його результатів, етики ділового спілкування під час аудиту, забезпечення незалежності аудиторської думки, контролю якості аудиторської діяльності;

2) повнотою застосування всіх аспектів МCA під час проведення аудиторської перевірки достовірності показників фінансової звітності;

3) незалежністю та неупередженістю аудиторської думки;

4) забезпеченням достовірності та адекватності аудиторської думки;

5) визначенням суттєвості в аудиті;

6) вибором та застосуванням аудиторських процедур відповідно до МСА.

Слід зазначити, що наші пропозиції мають вузько направлений характер, який забезпечує якісне отримання достовірних доказів при здійсненні безпо- середньо аудиторської перевірки. Безумовно, фактичний перелік проблем щодо аудиту фінансової звітності набагато більший, серед них:

1) нестабільність нормативної бази проведення аудиту форм фінансової звітності;

2) надання замовником аудиту неповної інформації або іiі приховування у зв'язку із відсутністю розуміння мети і завдань реального аудиту;

3) формальний підхід до проведення аудиту через брак інформації;

4) намагання стандартизувати фінансову звітність відповідно до міжнародних стандартів без урахування особливостей діяльності вітчизняних підприємств [15].

Задля вирішення проблем аудиту фінансової звітності та фінансового аудиту в цілому, пропонуються різні заходи, які мають здійснюватися на чотирьох рівнях: на міжнародному та національному законодавчому рівнях; на рівні органу регулювання аудиторської діяльності; на рівні виконавців аудиту (аудиторів, аудиторських компаній); на рівні замовників аудиту (засновників та керівництва підприємства) (табл. 4).

Таблиця 4

\section{Напрями вдосконалення аудиту фінансової звітності*}

\begin{tabular}{|c|c|}
\hline $\begin{array}{c}\text { Рівень } \\
\text { вдосконалення }\end{array}$ & Напрями вдосконалення \\
\hline $\begin{array}{l}\text { 1. На міжнародному та } \\
\text { національному законо- } \\
\text { давчому рівнях }\end{array}$ & $\begin{array}{l}\text { - створення ефективної та досконалої системи законодавчого врегулювання про- } \\
\text { ведення та реалізації результатів аудиту [16]; } \\
\text { - підвищення престижу аудиторської професії [17]; } \\
\text { - удосконалення навчальних планів підготовки обліковців та майбутніх аудиторів } \\
\text { у ВНЗ [17] }\end{array}$ \\
\hline $\begin{array}{l}\text { 2. На рівні органу регу- } \\
\text { лювання аудиторської } \\
\text { діяльності }\end{array}$ & $\begin{array}{l}\text { - максимальне наближення методологічних засад бухгалтерського обліку до ви- } \\
\text { мог міжнародних стандартів [16]; } \\
\text { - створення ефективної та досконалої системи контролю якості аудиту [16]; } \\
\text { - розробка механізму ціноутворення в сфері аудиту шляхом вивчення міжнарод- } \\
\text { ного досвіду з цього питання [17] }\end{array}$ \\
\hline $\begin{array}{l}\text { 3. На рівні виконавців } \\
\text { аудиту (аудиторів, ау- } \\
\text { диторських компаній) }\end{array}$ & $\begin{array}{l}\text { - удосконалення документального оформлення аудиторської перевірки [16;17]; } \\
\text { - розробка та застосування внутрішньо фірмових стандартів аудиту [16]; } \\
\text { - зменшення обсягу «тіньового» бізнесу [16] }\end{array}$ \\
\hline $\begin{array}{l}\text { 4. На рівні замовників } \\
\text { аудиту (засновників та } \\
\text { керівництва підприємс- } \\
\text { тва) }\end{array}$ & $\begin{array}{l}\text { - знайомство керівників підприємства із основами формування фінансової звіт- } \\
\text { ності, освоєння навику її «читання»; } \\
\text { - підвищення рівня поінформованості керівників підприємств } 3 \text { питань аудитор- } \\
\text { ських перевірок [17] }\end{array}$ \\
\hline
\end{tabular}


За результатами проведеного дослідження вважаємо за потрібне рекомендувати теоретикометодологічні заходи для вдосконалення організації та здійснення аудиту фінансової звітності, задля забезпечення прийняття якісних управлінських рішень за даними фінансової звітності, до яких відносимо:

1) розробка та запровадження Міжнародного стандарту аудиту «Аудиторські процедури обов'язкового аудиту фінансової звітності»;

2) уточнення переліку аудиторських процедур аудиту фінансової звітності, в тому числі обов'язкового аудиту, на рівні аудиторської палати України;

3) розробка Методичних рекомендацій щодо застосування аудиторських процедур для забезпечення якості аудиторського висновку про достовірність показників фінансової звітності;

4) розробка Методичних рекомендацій на рівні АПУ щодо визначення рівня суттєвості для фінансової звітності взагалі та окремих процедур аудиту;

5) організація і проведення семінарів АПУ або САУ в межах підвищення кваліфікації аудиторів України за напрямком «Суттєвість та процедури обов'язкового аудиту фінансової звітності»;

6) розробка внутрішньо фірмових стандартів та застосування спеціальної документації щодо планування, реалізації та відображення результатів аудиторських процедур;
7) підвищення рівня поінформованості замовників аудиту фінансової звітності з питань необхідності застосування аудиторських процедур.

Висновки та напрями подальших досліджень. Аудит фінансової звітності є дієвим інструментом забезпечення користувачів фінансової звітності достовірною інформацією для прийняття стратегічних рішень, в тому числі, рішень і системі управління підприємством. При цьому, мета сучасної аудиторської компанії - досягти рівня аудиторських процедур, документування і якості комунікацій, що відповідають найкращій світовій практиці. Запропоновані нами заходи сприятимуть як вдосконаленню методики проведення аудиторської перевірки достовірності показників фінансової звітності, так і розвитку аудиторської діяльності в цілому. Також вважаємо важливим той факт, що застосування зазначених в статті аудиторських процедур забезпечує вирішення проблемних питань, пов'язаних із забезпеченням відповідної якості звітної інформації для прийняття дієвих управлінських рішень. Тематика розробки та застосування аудиторських процедур об'ємна та багатогранна. В майбутніх наукових дослідженнях планується розкрити проблематику застосування інструментарію та технології процедури аудиторського підтвердження. За нашим уявленням, достовірність аудиту фінансової звітності досягається отриманням відповідних доказів суттєвих тверджень фінансової звітності шляхом застосування адекватних аудиторських процедур на кожному етапі аудиторської перевірки.

\section{Література}

1. Одінцов Л.М, Титаренко А.О., Швець М.В. Система фінансового контролю і розвиток аудиторства в Україні // Вісник Кременчуцького державного політехнічного університету. 2012. № 1. С. 47.

2. Міжнародні стандарти контролю якості, аудиту, огляду, іншого надання впевненості та надання супутніх послуг. Видання 2016-2017 років. Частина І. Переклад з англійської мови. К.:Видавництво «Фенікс». 2017. $1142 \mathrm{c}$.

3. Про аудит фінансової звітності та аудиторську діяльність в Україні: Закон України за станом на 19.06.2020р./ Верховна рада України. Законодавство України: веб-сайт. URL: http://zakon4.rada.gov.ua/laws. (дата звернення: 15.04.2021).

4. Про бухгалтерський облік і фінансову звітність в Україні: Закон України за станом на 14.11.2020р./ Верховна рада України. Законодавство України: веб-сайт. URL: http://zakon4.rada.gov.ua/laws. (дата звернення: 15.04.2021).

5. Загальні вимоги до фінансової звітності: Національне положення (стандарт) бухгалтерського обліку 1, затв. наказом Міністерства фінансів України від 2 серпня 2014 року № 48 за станом на 23.07.2019 р. / Законодавство України: веб-сайт. URL: http://zakon4.rada.gov.ua/laws/show/z0336- 13. 3. (дата звернення: 15.04.2021).

6. Аудит в Україні. Основи державного, незалежного професійного та внутрішнього аудиту: підручник / за ред. проф. Немченко В.В., Редько К.О. Київ: Центр учбової літератури, 2012. 536 с.

7. Остап'юк Н.А. Проблеми нормативного регулювання організації аудиторської діяльності // Міжнародний збірник наукових праць. Випуск 2(17). 2017. С. 250-253.

8. Фальченко О.О., Лозенко О.А. Критерії аудиторської оцінки фінансової звітності // Східна Європа: економіка, бізнес та управління. Випуск 6 (23). 2019. С. 715-719.

9. Петренко Н.І. Методика аудиту фінансової звітності та шляхи їі удосконалення // Вісник ЖДТУ. 2010. №1. C. $230-236$.

10. Ратліфф Р.Л. Посібник по аудиторських доказах. URL: http://findarticles. com/p/articles/mi_m4153 /is_n4_v55/ai_21119269. (дата звернення: 20.04.2021).

11. Кулик Р.Р. Етимологія поняття «суттєвість» у бухгалтерському обліку та аудиті // Економічний аналіз. 2014. Т. 18. № 2. С. 23-30.

12. Мултанівська Т.В., Воінова Т.С. Організація і методика аудиту: практикум. Харків: ХНЕУ ім. С. Кузнеця, 2016. 284 с. 
13. Рядська В.В. Суттєвість як об'єкт аудиторського дослідження та критерій оцінювання достовірності фінансової звітності // Вісник ЧДТУ. 2013. № 3(68). С. 226-231.

14. Словник української мови. Словник-uа - Портал української мови та культури. URL: https://slovnyk.ua/index.php?swrd. (дата звернення: 20.04.2021)

15. Амеліна Ю.Ю. Проблеми покращення якості аудиту фінансової звітності та напрями його вдосконалення в умовах міжнародних стандартів // Управління розвитком. 2011. №2. С. 11-13.

16. Артюх О.В., Красовський В.В. Проблеми аудиту фінансової звітності // Удосконалення бухгалтерського обліку та оподаткування на сучасному етапі розвитку економіки України: матеріали кафедральної студентської конференції, м. Ірпінь, 29 листопада 2018 р. / Університет ДФС України, 2018. 116 с.

17. Дулачик О. І., Кушнір А. М., Мариняк О.О. Сучасний стан, проблеми та перспективи розвитку аудиту в Україні / Розвиток соціально-економічних систем в геоекономічному просторі: теорія, методологія, організація обліку та оподаткування: матеріали міжнародної наук.-практ. конф., м. Тернопіль, 11-12 травня 2017 р. / ТНТУ ім. І. Пулюя, м. Тернопіль, 2017. С. 81-82.

Стаття надійшла 24.04.2021

Стаття прийнята до друку 8.05.2021

Доступно в мережі Internet 21.07.2021

Tkachuk H.

Doctor of Economics, Associate Professor

Department of Accounting and Auditing

E-mail: talla2007@ukr.net

ORCID ID: 0000-0001-6937-6223

Skliar L.

Ph.D., Associate Professor

Department of Accounting and Auditing

E-mail: sklyarlarisa17@gmail.com

ORCID ID: 0000-0002-8332-8823
Ivanchenkova L.

Doctor of Economics, Professor

Department of Accounting and Auditing

E-mail: ivanchenkovalarisa@gmail.com

ORCID ID: 0000-0002-8461-7846

Stupnytska T.

Ph.D., Associate Professor

Department of Accounting and Auditing

Odesa National Academy of Food Technologies

Kanatna str., 112, Odesa, Ukraine, 65039

E-mail: t.stupnitska@gmail.com

ORCID ID: 0000-0002-2517-2795

\section{AUDIT PROCEDURES FOR CONFIRMATION OF FINANCIAL STATEMENTS AUTHENTICITY: SOLVING OF THE PROBLEMS}

The financial statements of the enterprise are the main source of information about the results of economic activity, financial and property status of the food industry for a large group of users of different levels. The relevance of the research chosen by the authors of this article is justified by the need to improve the theoretical and methodological basis for obtaining reliable information in financial statements to ensure effective management decisions based on the analysis of such financial statements. The list of problematic issues of the audit of financial statements has been outlined, the solution of which is aimed at ensuring the reliability of the information of the financial statements, concluded according to national and international standards. The place of normative support of audit in ensuring the quality of reporting information has been determined. The main criteria for the audit of financial statements have been summarized, their content has been determined and appropriate explanations have been given. The authors highlight the problematic issues of enterprise management, which are solved by conducting an independent audit or the use of audit procedures in the internal control system of the enterprise. The category of "materiality" in the audit of financial statements has been studied, its essence and content have been determined by specific types in accordance with the requirements of International Standards on Auditing. The characteristics of materiality factors at the level of specific classes of operations have been given. The audit procedures that need to be applied to ensure the reliability of the results of the audit of financial statements have been identified. The classification of directions of improvement of audit of the financial reporting according to a level of their realization has been presented. Practical measures have been proposed to improve the organization and audit of financial statements. Conclusions have been made on further research in this area. The results of this study allow us to expand our understanding of the materiality of the audit and the application of audit procedures to ensure the reliability of the audit opinion. The work is of practical importance, as the use of the proposed measures allows to improve existing approaches to the collection of audit evidence, expands the possibilities of ensuring the quality of reporting information of the enterprise.

Key words: audit, audit opinion, International auditing standards, financial statements, materiality in the audit, audit procedures, examination, enterprise management. 


\section{References}

1. Odintsov, L. M, Tytarenko, A. O., \& Shvets, M. V. (2012). Systema finansovoho kontroliu i rozvytok audytorstva v Ukraini. Visnyk Kremenchutskoho derzhavnoho politekhnichnoho universytetu, (1), 47.

2. Mizhnarodni standarty kontroliu yakosti, audytu, ohliadu, inshoho nadannia vpevnenosti ta nadannia suputnikh posluh. Vydannia 2016-2017 rokiv. (2017). P. 1. Vydavnytstvo «Feniks».

3. Pro audyt finansovoi zvitnosti ta audytorsku diialnist v Ukraini: Zakon Ukrainy za stanom na 19.06.2020 r. Verkhovna rada Ukrainy. Zakonodavstvo Ukrainy. http://zakon4.rada.gov.ua/laws.

4. Pro bukhhalterskyi oblik $i$ finansovu zvitnist $v$ Ukraini: Zakon Ukrainy za stanom na 14.11.2020 r. Verkhovna rada Ukrainy. Zakonodavstvo Ukrainy. http://zakon4.rada.gov.ua/laws.

5. Zahalni vymohy do finansovoi zvitnosti: Natsionalne polozhennia (standart) bukhhalterskoho obliku 1, zatv. nakazom Ministerstva finansiv Ukrainy vid 2 serpnia 2014 roku № 48 za stanom na 23.07.2019 r. Zakonodavstvo Ukrainy. http://zakon4.rada.gov.ua/laws/show/z0336-13. 3.

6. Nemchenko, V. V., \& Redko, K. O. (Eds.). (2012). Audyt v Ukraini. Osnovy derzhavnoho, nezalezhnoho profesiinoho ta vnutrishnoho audytu. Tsentr uchbovoi literatury.

7. Ostap'iuk, N. A. (2017). Problemy normatyvnoho rehuliuvannia orhanizatsii audytorskoi diialnosti. Mizhnarodnyi zbirnyk naukovykh prats, (2(17), 250-253.

8. Falchenko, O. O., \& Lozenko, O. A. (2019). Kryterii audytorskoi otsinky finansovoi zvitnosti. Skhidna Yevropa: ekonomika, biznes ta upravlinnia, (6 (23), 715-719.

9. Petrenko, N. I. (2010). Metodyka audytu finansovoi zvitnosti ta shliakhy yii udoskonalennia. Visnyk ZhDTU, (1), $230-236$.

10. Ratliff, R. L. Posibnyk po audytorskykh dokazakh. http://findarticles. com/p/articles/mi_m4153 /is_n4_v55/ai_21119269.

11. Kulyk, R. R. (2014). Etymolohiia poniattia «suttievist» u bukhhalterskomu obliku ta audyti. Ekonomichnyi analiz, 18(2), 23-30. Kuznetsia.

12. Multanivska, T. V., \& Voinova, T. S. (2016). Orhanizatsiia i metodyka audytu: praktykum. KhNEU im. S.

13. Riadska, V. V. (2013). Suttievist yak ob'iekt audytorskoho doslidzhennia ta kryterii otsiniuvannia dostovirnosti finansovoi zvitnosti. Visnyk ChDTU, (3(68), 226-231.

14. Slovnyk ukrainskoi movy. Slovnyk-ua - Portal ukrainskoi movy ta kultury. https://slovnyk.ua/index.php?swrd

15. Amelina, Yu. Yu. (2011). Problemy pokrashchennia yakosti audytu finansovoi zvitnosti ta napriamy yoho vdoskonalennia v umovakh mizhnarodnykh standartiv. Upravlinnia rozvytkom, (2), 11-13.

16. Artiukh, O. V., \& Krasovskyi V. V. (2018). Problemy audytu finansovoi zvitnosti. In materialy kafedralnoi studentskoi konferentsii: Udoskonalennia bukhhalterskoho obliku ta opodatkuvannia na suchasnomu etapi rozvytku ekonomiky Ukrainy (p. 116), Irpin; Universytet DFS Ukrainy.

17. Dulachyk, O. I., Kushnir, A. M., \& Maryniak, O. O. (2017). Suchasnyi stan, problemy ta perspektyvy rozvytku audytu v Ukraini. In materialy mizhnarodnoi nauk.-prakt. konf.: Rozvytok sotsialno-ekonomichnykh system $v$ heoekonomichnomu prostori: teoriia, metodolohiia, orhanizatsiia obliku ta opodatkuvannia (pp. 81-82), Ternopil; TNTU im. I. Puliuia.

Received 24 April 2021

Approved 8 May 2021

Available in Internet 21.07.2021

Цитування згідно ДСТУ 8302:2015

Ткачук Г.О., Іванченкова Л.В., Скляр Л.Б., Ступницька Т.М. Процедури аудиторського підтвердження достовірності фінансової звітності: вирішення проблемних питань // Економіка харчової промисловості. 2021. Т.13, вип. 2. С. 95-104. doi: 10.15673/fie.v13i2.2045

Cite as APA style citation

Tkachuk, H., Ivanchenkova, L., Skliar, L., \& Stupnytska, T. (2021). Audit procedures for confirmation of financial statements authenticity: solving of the problems. Food Industry Economics, 13(2), 95-104. doi: 10.15673/fie.v13i2.2045 